\title{
Estimation of Peat Surface Carbon Stocks on The Semenanjung Kampar from Land Use Changes Using Landsat Multi-Temporal in 2009-2018
}

\author{
*Yudi Antomi and Ristalia \\ *Remote Sensing Technology Study Program, Universitas Negeri Padang, Indonesia \\ Email: antomi_y@fis.unp.ac.id
}

*Corresponding Author, Received: Februari 10, 2019, Revised: April 10, 2019, Accepted: May 10, 2019

This is an open acces article distributed under the Creative Commons 4.0 Attribution License, wich permits unrestricted use, Distribution, and reproduction in any medium provided the original work is properly cited @2017 by author and Universitas Negeri Padang

\begin{abstract}
Remote sensing has advantages in terms of temporal resolution that can be used to check changes in an object at different times. The Semenanjung Kampar peatland underwent land use change after the change in PP No. 71 of 2014 became PP No. 57 of 2016 which requires companies (paper companies) to restore the ecosystem on the Semenanjung Kampar. These changes were analyzed by utilizing remote sensing technology through multi-temporal imagery. This study aims to analyze changes in peatland use on the Semenanjung Kampar in 2009, 2013 and 2018, then estimate carbon stocks from changes in peatland use. The method used is the classification of Iso Cluster unsupervised and calculation of increase and decrease in carbon stocks (Gain and Loss). Based on this research the results of the accuracy of the classification of changes in land use on the Semenanjung Kampar were 0.72 or $72 \%$.Changes in land use on the Semenanjung Kampar occur dynamically. The dominant land change for the 2009-2013 period was shrubs which became acacia forests 89386.31 ha and bushes from 2013-2018 to oil palm plantations 57878.47 ha. Furthermore, carbon stocks in the period 2009-2013 that have increased (acces) are 8.2\% acacia forest and 13\% decrease in primary peat forest while the 2013-2018 period has increased, namely $8 \%$ oil palm plantation and $21 \%$ shrub decline.
\end{abstract}

Keywords: Remote Sensing, Peatland, Land Use Change, Gain and Loss, Carbon Stock

\section{Introduction}

The Semenanjung Kampar area is one of the largest stretches of peat swamp forest in Riau Province. Georaphically, the Semenanjung Kampar is bordered on the south by the Kampar River to the north by the Siak River, east to the Long Strait and to the west by oil palm plantations and Industrial Plantation Forests. Administratively, the Semenanjung Kampar area is in Pelalawan District and Siak Regency. The Semenanjung Kampar has a peat forest ecosystem that is located between 2 (two) large rivers, namely the Siak River and Kampar River. Almost all of the Semenanjung Kampar area is peat dome with peat dome as its core area with a deep peat depth that is very deep and some small peat domes (Qomar and Jaya, 2010).

The existence of the Semenanjung Kampar peat swamp forest ecosystem is under considerable pressure and the area has changed significantly (Rifardi, 2008; Qomar and Jaya, 2010). The opening of forests and peatlands for agriculture, industrial plantations and plantations accompanied by massive and uncontrolled canal production is expected to change the hydrological pattern to extremes (Siegel et al., 1995).Peat experiences excessive drying to damage the colloidal properties of peat into flammable materials and increases the risk of forest and land fires (Hooijer et al., 2006).The cover area of peat swamp forest in the Semenanjung Kampar in 1982 reached $97 \%$ of the total area of 70,129 hectares.In 2005 the forest cover area only reached $63 \%$ or $34 \%$ of deforestation in 23 years (1982-2005) from the total area of the Semenanjung Kampar or around 260,348 hectares (Rifardi, 2008). 
Based on the problem of changes in land use (Hermon, 2012; Hermon, 2015; Hermon, 2016; Hermon, 2017), degradation and deforestation of peatlands on the Semenanjung Kampar from time to time.Given the role and function of peatlands which have large carbon content, and control changes in micro and macro climate.hence in this case a study was conducted to analyze changes in peatland use on the Semenanjung Kampar from the period 2008 to 2013 and 2013 to 2018.Data on the extent of changes in peatland use were then calculated based on carbon stocks contained on the surface of peatlands. So that there will be a trend in the surface carbon stock of peatlands on the Semenanjung Kampar from period to period.

\section{Method}

The method used in the analysis of land use in the Semenanjung Kampar in 2009-2018, namely the classification of the Iso Cluster unsupervised, as for the algorithms used in the classification of the Iso Cluster unsupervised in the Arc Arc Arc toolbox are as follows:

$$
Z=\frac{(\mathrm{X}-\text { oldmin }) \times(\text { newmox }- \text { newmin })}{(\text { oldmox }- \text { oldmin })}+\text { newmin }
$$

(Richards, J. A. 1986), (Ball, G. H., and D. J. Hall. 1965)....(1)

While the calculation of the increase and decrease in carbon stocks (Gain and Loss). With the formula as follows:

$$
\begin{array}{|l|}
\Delta \mathrm{C}=\Delta \mathrm{C}_{\mathrm{G}}-\Delta \mathrm{C}_{\mathrm{L}} \\
\text { IPCC, } 2006 \ldots \ldots \ldots \ldots(2)
\end{array}
$$

\section{Result and Discussion}

\section{Analysis of Changes in Land Use}

Land use on the Semenanjung Kampar from 2009 to 2013 was dominated by secondary peat forests, shrubs, primary peat forests, and acacia forests. Dynamics of changes in land use on the Semenanjung Kampar in 2009 to 2013 (Figure 1). In the period of 2009 to 2013 the acacia forest area experienced a significant increase of $5.3 \%$ from $2.3 \%$. Whereas shrubs have decreased by $9.1251,5$ ha or $13.4 \%$. In the 2013 to 2018 period the type of land use experienced a significant increase, namely oil palm plantations covering an area of 6.6757 ha or $9.8 \%$, while the type of land use that experienced a decrease was open peatland and shrubs of $7 \%$ and $9 \%$.

\begin{tabular}{|c|c|c|c|c|c|c|c|}
\hline No & Land use & 2009 & $\%$ & 2013 & $\%$ & 2018 & $\%$ \\
\hline 1 & Acacia forest & 18959,9 & 2,8 & 101598 & 14,9 & 158096,3 & 23,1 \\
\hline 2 & Primary peat forest & 103523,2 & 15,2 & 66505 & 9,7 & 66619,4 & 9,8 \\
\hline 3 & Secondary peat forest & 243848,5 & 35,7 & 278845,5 & 40,8 & 264439,4 & 38,7 \\
\hline 5 & Open peat land & 63485,7 & 9,3 & 61198,7 & 9,0 & 13692,8 & 2,0 \\
\hline 6 & Shrubs & 246329,7 & 36,1 & 155078,2 & 22,7 & 93625,7 & 13,7 \\
\hline 7 & Water & 4616,3 & 0,7 & 4589,1 & 0,7 & 4587,8 & 0,7 \\
\hline
\end{tabular}

Table 1. Land Use Classification in 2009, 2013 and 2018.

Source: Processed Landsat Imagery (2018)

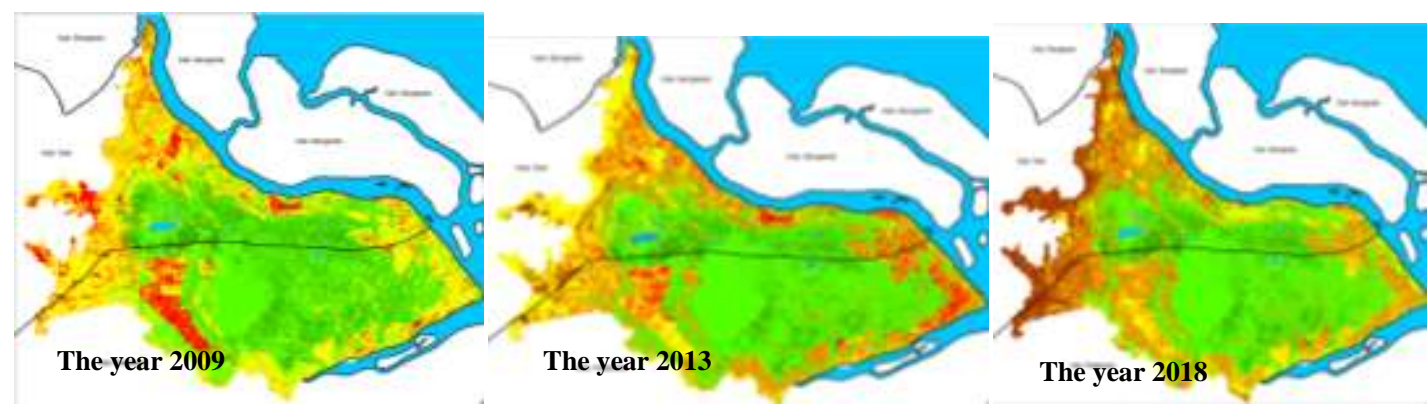




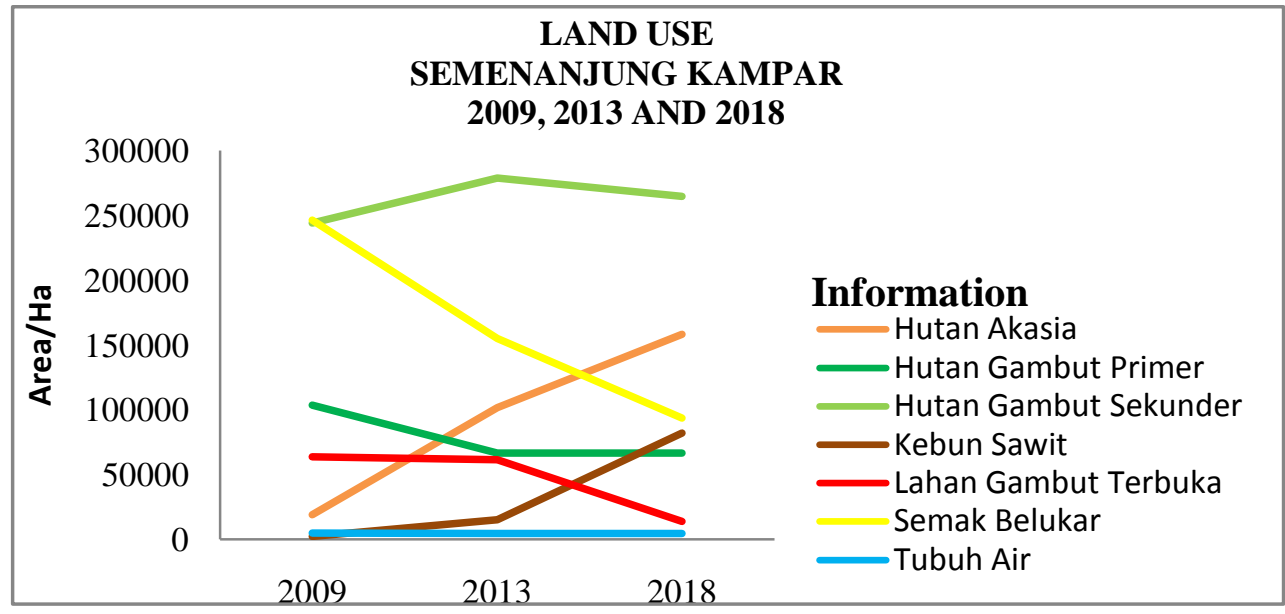

Figure 1. Changes in land use on the Semenanjung Kampar in 2009, 2013 and 2018 Source: Processed landsat imagery, 2018

Based on the picture above, the trend of changes in land use that experienced a significant increase from 2009 to 2018 was acacia and oil palm plantations, while those experiencing a significant decline were open peatlands and shrubs.

\section{Estimates of Peatland Surface Carbon Reserves}

Changes in land use have a large impact on the Semenanjung Kampar. One of them is the surface carbon stock of peatlands. Data on land use change analysis in 2009, 2013 and 2018 formed the basis for calculating estimates of the loss of surface carbon stocks of peatlands on the Semenanjung Kampar. The method used in this calculation is the calculation of the increase and supply of carbon stocks (Gain and Loss) that compares carbon stocks in the initial year with the nth year. The following is a table for analyzing peatland carbon stocks based on the type of land use on the Semenanjung Kampar in 2009, 2013 and 2018:

Table 2. Peatland Carbon Stock Based on Land Use on the Semenanjung Kampar in 2009, 2013 and 2018.

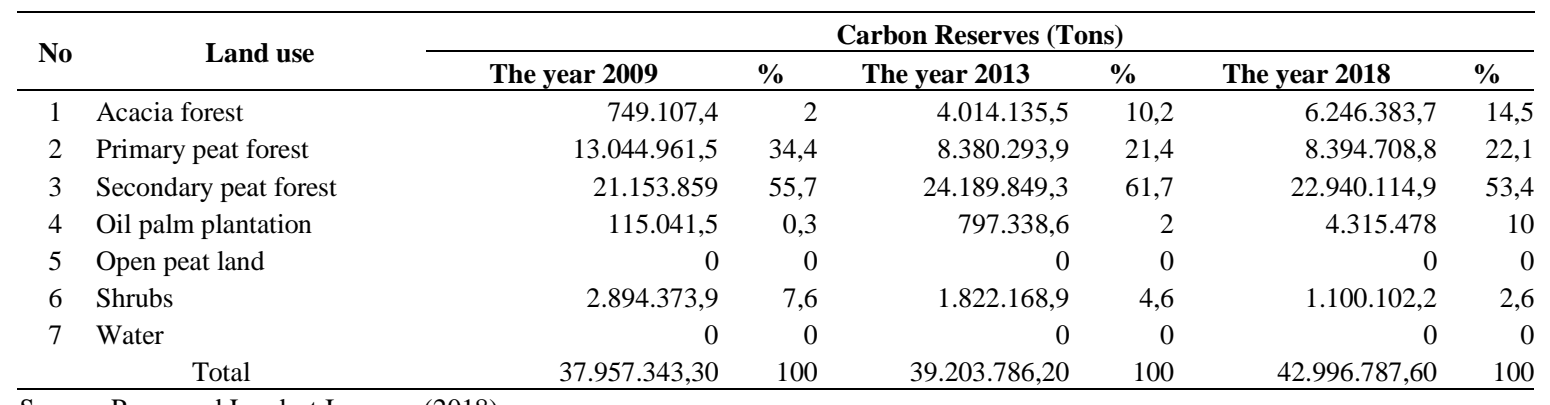

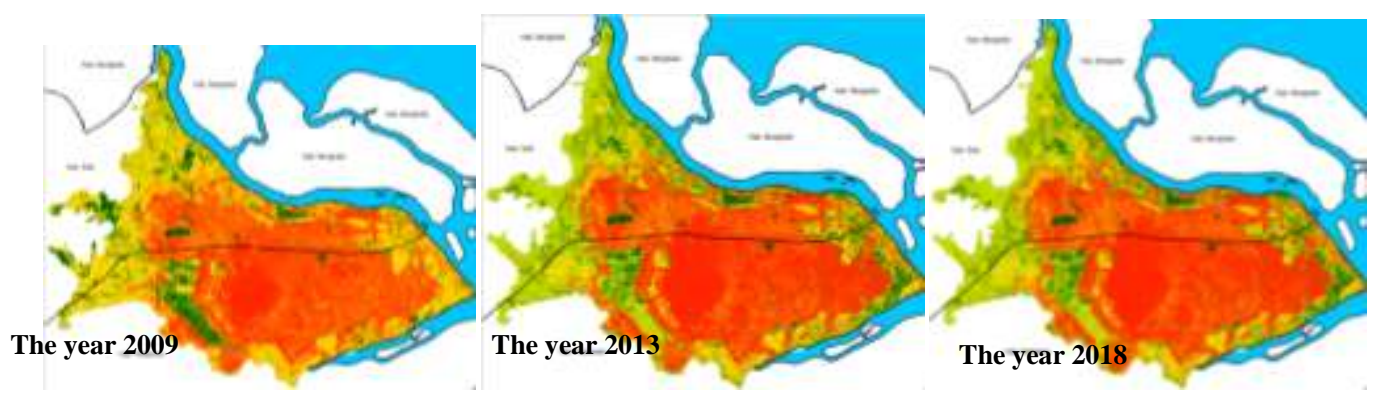




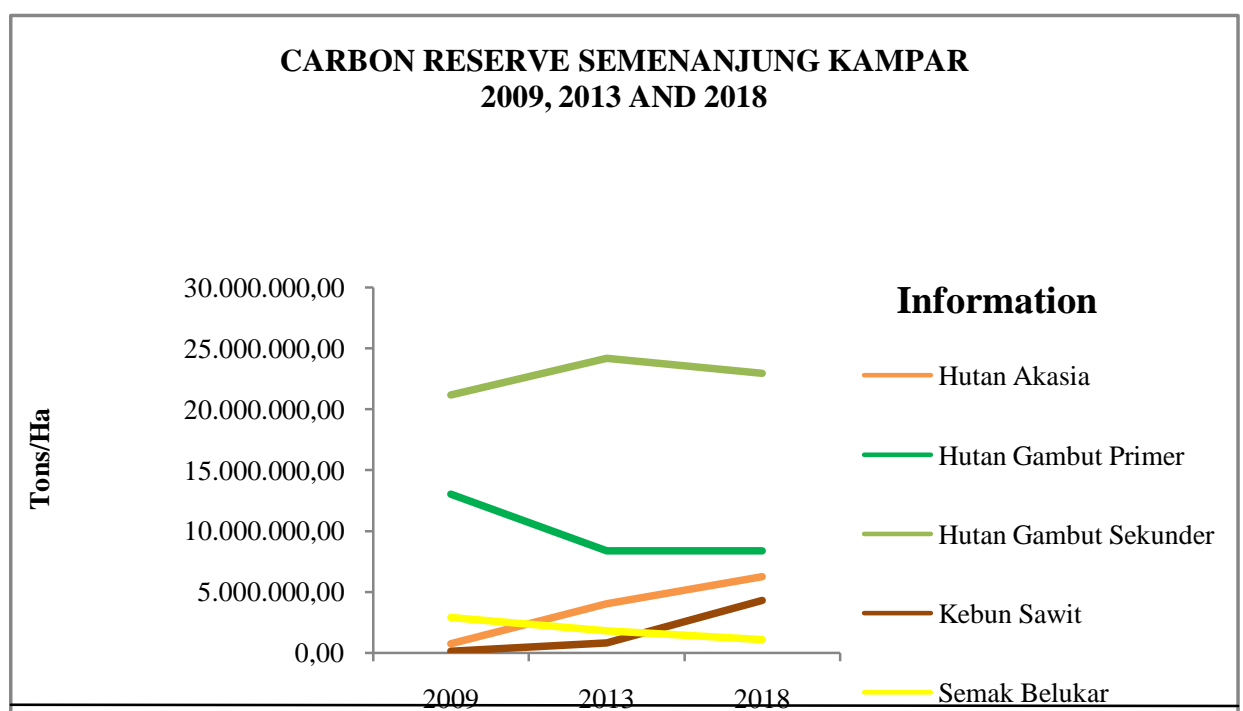

Figure 2. Map of The Surface Carbon Stock of Peatlands on the Semenanjung Kampar in 2008, 2013 and 2018

Source: Processed Landsat Imagery (2018)

Based on the map of carbon stocks on the Semenanjung Kampar in 2009, 2013 and 2018 below. It can be seen that the highest carbon reserves are scattered in the central part of the Kampar which is dominated by primary peat forests and secondary peat forests, while the lowest carbon reserves are spread in the southern and border areas of the Kampar with Siak Regency. Based on the graph above, it can be seen that each type of land use experiences a trend of changes in carbon stocks. Carbon stocks always increase, namely acacia forest carbon stocks and oil palm plantations. Whereas the decline was in the form of scrub land use carbon stocks.

Table 3. Changes in Carbon Stocks in The Period 2009 - 2013 and 2013 - 2018

\begin{tabular}{llrrr}
\hline \multirow{2}{*}{ No } & & \multicolumn{2}{c}{ Carbon Reserves (Tons) } \\
\cline { 3 - 5 } & & $\mathbf{2 0 0 9 - 2 0 1 3}$ & \% & $\mathbf{2 0 1 3 - 2 0 1 8}$ \\
\hline 1 & Acacia forest & $+3.265 .028,0$ & $+8,3$ & $+2.232 .248,2$ \\
2 & Primary peat forest & $-4.664 .667,6$ & -13 & $+4,3$ \\
3 & Secondary peat forest & $+3.035 .990,3$ & +6 & $-14.414,9$ \\
4 & Oil palm plantation & $+682.297,0$ & $+1,7$ & $-1.249 .734,4$ \\
5 & Open peat land & 0 & $-8,3$ \\
6 & Shrubs & $-1.072 .204,9$ & -3 & $+3.518 .139,4$ \\
7 & Water $\quad$ Total & 0 & 0 \\
& & $+1.246 .442,9$ & $-722.066,8$ \\
\end{tabular}

Information: (-) losses (+) gains

Source: Processed landsat imagery, 2018

\section{Conclusion}

It can be concluded that, the Semenanjung Kampar in the period 2009 - 2013 experienced changes in land use dynamically. The land that has undergone the most changes is that the open peatland is transformed into shrubs, the primary peat forest is transformed into secondary peat forest and the shrubs turn into acacia forests. Whereas in the period 2013 - 2018, the land that experienced the most changes was that the open peatland turned into akasi forest, shrubs turned into oil palm plantations and shrubs turned into acacia forests. Changes in open peat land into shrubs, acacia forests and oil palm plantations, are one of the implementations of changes to Government Regulation No. 71 of 2014 became PP No. 57 of 2016 which requires companies (paper companies) to restore the ecosystem on the Semenanjung Kampar. One of them is by planting acacia trees and the like. So that this has a positive impact on the addition of carbon (Gains) in 
each period on the Semenanjung Kampar. The phenomenon of adding carbon stocks on the Semenanjung Kampar does not occur in every type of land use, such as primary peat forest transformed into secondary peat forest (Losses) and open peatland into acacia (Gains) forest, this change in land use causes disruption of the ecosystem balance on the Semenanjung Kampar. So that the addition of carbon stocks does not mean the condition of a good ecosystem on the Semenanjung Kampar.

\section{References}

Antomi, Y, Hermon, D, Dewata, I, Erianjoni, Razak, A, and Lanin, D, 2018. Model Habitat Quality In The Future In Padang City. International Journal of GEOMATE. Augustus 2018 Vol. 15, Issue 52, pp. 99-107.

Hermon, D. 2012. Mitigasi Bencana Hidrometeorlogi: Banjir, Longsor, Degradasi Lahan, Ekologi, Kekeringan, dan Puting Beliung. UNP Press. Padang.

Hermon, D. 2015. Geografi Bencana Alam. Jakarta: PT RajaGrafindo Persada.

Hermon, D. 2016. Mitigasi Perubahan Iklim. Rajawali Pers (Radjagrafindo).

Hermon, D. 2017. Climate Change Mitigation. Rajawali Pers (Radjagrafindo).

Hooijer, A., Silvius, M., Wösten, H. and Page, S., 2006. Peat- $\mathrm{CO}_{2}$, Assessment of $\mathrm{CO}_{2}$ Emissions from Drained Peatlands in SE Asia. Delft Hydraulics report Q3943.

IPCC. 2006. IPCC Guildenlines For National Greenhouse Inventories, Prepared by the National Greenhouse Gas Inventories Programme, Eggleston H.S., Buendia L., Miwa K., Ngara t. And Tanabe K. (eds. Published:IGES, Japan

Peraturan Pemerintah Republik Indonesia No. 57 tahun 2016 tentang tentang Pengendalian Kerusakan dan Pencemaran Lingkungan Hidup yang Berkaitan dengan Kebakaran Hutan dan atau Lahan.

Peraturan Pemerintah Republik Indonesia. No. 71 tahun 2014 tentang tentang Pengendalian Kerusakan dan Pencemaran Lingkungan Hidup yang Berkaitan dengan Kebakaran Hutan dan atau Lahan.

Qomar, N., dan Jaya, Y.V., 2010. Deforestasi dan Penggunaan Lahan Lansekap Semenanjung Kampar, Riau. Seminar dan Lokakarya Revitalisasi dan Penguatan Jejaring Kerjasama Pusat Penelitian Lingkungan Hidup, Pekanbaru 19-20 November 2010.

Richards, J. A. 1986. Remote Sensing Digital Image Analysis: An Introduction.. Berlin: Springer-Verlag.

Rifardi, 2008. Degradasi Ekologi Sumber daya Hutan dan Lahan (Studi Kasus Hutan Rawa Gambut Semenanjung Kampar Propinsi Riau). Jurnal Bumi Lestari, 8(2):145-154.

Siegel, D.I, Reeve, A.S., Glaser, P.H., and Romanowicz, E.A., 1995. Climate-Driver Flushing of Pore Water in Peatlands. Nature 374:531-533. 